\title{
Sodium/Calcium Exchange in Rat Cortical Astrocytes
}

\author{
William F. Goldman,, ${ }^{1,2,4}$ Paul J. Yarowsky, ${ }^{3}$ Magdalena Juhaszova, ${ }^{1}$ Bruce K. Krueger, ${ }^{1}$ and Mordecai P. \\ Blaustein ${ }^{1,2}$ \\ 'Departments of Physiology, ${ }^{2}$ Medicine, and ${ }^{3}$ Pharmacology and Experimental Therapeutics, University of Maryland \\ School of Medicine, and ${ }^{4}$ Geriatric Research, Education and Clinical Center, Baltimore VAMC, Baltimore, Maryland 21201
}

\begin{abstract}
Regulation of the cytosolic free $\mathrm{Ca}^{2+}$ concentration $\left(\left[\mathrm{Ca}^{2+}\right]_{\mathrm{cy}}\right)$ by an $\mathrm{Na} / \mathrm{Ca}$ exchanger was studied in primary cultured rat cortical astrocytes. $\left[\mathrm{Ca}^{2+}\right]_{\text {cyt }}$ was measured by digital imaging in cells loaded with fura-2. The resting $\left[\mathrm{Ca}^{2+}\right]_{\mathrm{cyt}} \approx 150$ $\mathrm{nM}$, was only slightly increased by reducing the extracellular $\mathrm{Na}^{+}$concentration $\left(\left[\mathrm{Na}^{+}\right]_{0}\right)$ to $6.2 \mathrm{~mm}$, or by treating the cells with ouabain for $\mathbf{1 5}$ min (to raise cytosolic $\mathrm{Na}^{+}$). Following treatment with ouabain, however, lowering $\left[\mathrm{Na}^{+}\right]_{0}$ caused $\left[\mathrm{Ca}^{2+}\right]_{\text {cyt }}$ to rise rapidly to $\approx 1300 \mathrm{nM}$. When $\mathrm{Ca}^{2+}$ sequestration in intracellular stores was blocked by thapsigargin, lowering $\left[\mathrm{Na}^{+}\right]_{0}$ increased $\left[\mathrm{Ca}^{2+}\right]_{\text {cyt }}$ to $\approx 1500 \mathrm{nM}$ in the absence of ouabain. The low-[Na+ $]_{0}$-stimulated rise in $\left[\mathrm{Ca}^{2+}\right]_{\text {eyt }}$ was abolished by removal of external $\mathrm{Ca}^{2+}$, but was not blocked by the $\mathrm{Ca}^{2+}$ channel blocker verapamil, or by caffeine or ryanodine, which deplete an intracellular $\mathrm{Ca}^{2+}$ store responsible for $\mathrm{Ca}^{2+}$-induced $\mathrm{Ca}^{2+}$ release. These data suggest that $\mathrm{Na}^{+}$gradient reduction promotes net $\mathrm{Ca}^{2+}$ gain via $\mathrm{Na} / \mathrm{Ca}$ exchange. Normally, however, a large rise in $\left[\mathrm{Ca}^{2+}\right]_{\text {cyt }}$ is prevented by sequestration of the entering $\mathrm{Ca}^{2+}$; this buffering of cytosolic $\mathrm{Ca}^{2+}$ can be circumvented by blocking sequestration with thapsigargin, or overwhelmed by enhancing net $\mathrm{Ca}^{2+}$ gain by pretreating the cells with ouabain. The presence of $\mathrm{Na} / \mathrm{Ca}$ exchanger protein and mRNA in the astrocytes was conflrmed by Western and Northern blot analyses, respectively. Immunohistochemistry revealed that exchanger molecules are distributed in a reticular pattern over the astrocyte surface. We suggest that the $\mathrm{Na} / \mathrm{Ca}$ exchanger plays a role in regulating both $\left[\mathrm{Ca}^{2+}\right]_{\text {cyt }}$ and the intracellular stores of $\mathrm{Ca}^{2+}$ in astrocytes, and may thus contribute to the control of astrocyte responsiveness to neurotransmitters and neurotoxins.
\end{abstract}

[Key words: astrocytes, digital imaging, cell culture, $\mathrm{Na}$ / Ca exchange, endoplasmic reticulum, thapsigargin, sodium, calcium]

\footnotetext{
Received Oct. 20, 1993; revised Mar. 31, 1994; accepted Apr. 21, 1994.

We thank Dr. G. E. Lindenmayer for providing the anti-Na/Ca exchanger antiserum and canine cardiac sarcolemma, and Drs. P. Kofuji, W. J. Lederer, and D. H. Schulze for the rat cardiac $\mathrm{Na} / \mathrm{Ca}$ exchanger cDNA probe. We also thank Drs. M. L. Borin and V. A. Golovina for helpful comments on the manuscript. We are grateful to Dr. Golovina for permission to mention unpublished data, and to Dr. X.-J. Yuan for assistance with the membrane potential measurements. This work was supported by NIH Grants HL-43091 to W.F.G., NS-16106 to M.P.B., and NS-16285 and AG-10686 to B.K.K., and by NSF Grant BNS-8919892 to P.J.Y.

Correspondence should be addressed to Mordecai P. Blaustein, M.D., Department of Physiology, University of Maryland School of Medicine, 655 West Baltimore Street, Baltimore, MD 21201.
}

Copyright (C) 1994 Society for Neuroscience $0270-6474 / 94 / 145834-10 \$ 05.00 / 0$
Recent evidence suggests that astrocytes play a much more significant role in the functioning of the mammalian nervous system than had been previously thought. In addition to such wellestablished functions as regulation of the extracellular $\mathrm{K}^{+}$concentration $\left(\left[\mathrm{K}^{+}\right]_{o}\right)$ and clearance of excitotoxic agents such as glutamate, astrocytes respond to a variety of neurotransmitters and neuromodulators, and they carry out complex intracellular and intercellular signaling (Cornell-Bell et al., 1990; Glaum et al., 1990; Jensen and Chiu, 1990; Barres, 1991; Charles et al., 1991; McCarthy and Salm, 1991). A central feature of these responses is a rise in the ionized cytoplasmic $\mathrm{Ca}^{2+}$ concentration $\left(\left[\mathrm{Ca}^{2+}\right]_{\mathrm{cy}}\right)$. Within individual cells, $\left[\mathrm{Ca}^{2+}\right]_{\mathrm{cyt}}$ often undergoes a series of oscillations (Cornell-Bell et al., 1990; Jensen and Chiu, 1990; Charles et al., 1991). Moreover, the increase in $\left[\mathrm{Ca}^{2+}\right]_{\mathrm{cyt}}$ can propagate from cell to cell in cultures in which the cells are electrically coupled (Cornell-Bell et al., 1990; Charles et al., 1991). Such waves of $\left[\mathrm{Ca}^{2}\right]_{\text {cyt }}$ may propagale over many cells throughout an astrocyte syncytium both in vitro and in vivo. It has been suggested that the increase in $\left[\mathrm{Ca}^{2+}\right]_{\mathrm{cyt}}$ not only mediates the actions of neurotransmitters within individual cells (McCarthy and Salm, 1991), but may also serve as an intercellular signaling mechanism parallel to and independent of the electrical signals carried out by action potentials in neurons (Cornell-Bell et al., 1990).

A component of the astrocyte $\left[\mathrm{Ca}^{2+}\right]_{\mathrm{cyt}}$ response appears to be mediated by extracellular $\mathrm{Ca}^{2+}$ entry through voltage-gated $\mathrm{Ca}^{2+}$ channels (Barres et al., 1990; MacVicar et al., 1991). However, much of the response, including both oscillations and propagated waves (both intracellular and intercellular), require inositol 1,4,5-trisphosphate $\left(\mathrm{IP}_{3}\right)$ synthesis and the release of $\mathrm{Ca}^{2+}$ from $\mathrm{IP}_{3}$-sensitive intracellular stores in the endoplasmic reticulum (ER) (Ahmed et al., 1990; Cornell-Bell et al., 1990; Glaum et al., 1990). Such intracellular $\mathrm{Ca}^{7+}$ stores in a varicty of cell types accumulate $\mathrm{Ca}^{2+}$ via a specific ATP-dependent pump that is inhibited by compounds such as thapsigargin and cyclopiazonic acid (Seidler et al., 1989; Thastrup et al., 1990); $\mathrm{Ca}^{2+}$ is also released from ER stores by caffeine and ryanodine (Palade et al., 1987; McPherson et al., 1991). These stores undoubtedly play a crucial role in buffering transient increases in $\left[\mathrm{Ca}^{2+}\right]_{\mathrm{cy}}$; nevertheless, in the steady-state, all $\mathrm{Ca}^{2}$ that enters from the extracellular space must be extruded against a large electrochemical gradient. Two types of processes can mediate this net $\mathrm{Ca}^{2+}$ extrusion across the plasmalemma: an ATP-driven $\mathrm{Ca}^{2+}$ pump (Schatzmann, 1982) and $\mathrm{Na} / \mathrm{Ca}$ exchange (Blaustein et al., 1991a,b). Moreover, the $\mathrm{Na} / \mathrm{Ca}$ exchanger also mediates net $\mathrm{Ca}^{2+}$ influx upon reduction of the $\mathrm{Na}^{+}$electrochemical gradient. To understand the mechanisms that regulate $\left[\mathrm{Ca}^{2+}\right]_{\mathrm{cyt}}$, and therefore the magnitude of the cell's response to external stimuli, we 
must take into account $\mathrm{Ca}^{2+}$ sequestration into and release from internal stores as well as the activities of the plasmalemmal $\mathrm{Ca}^{3+}$ transport mechanisms.

The focus of this report is the plasmalemmal $\mathrm{Na} / \mathrm{Ca}$ exchanger. Several studies have demonstrated that $\left[\mathrm{Ca}^{2+}\right]_{\text {cyt }}$ in astrocytes is influenced by the $\mathrm{Na}^{+}$electrochemical gradient across the plasmalemma (reviewed in Finkbeiner, 1993): $\mathrm{Ca}^{2+}$ entry (Lazarewicz et al., 1977; Kim-Lee et al., 1992) and $\left[\mathrm{Ca}^{2+}\right]_{\text {cyt }}$ (Blaustein et al., 1991; Cornell-Bell and Finkbeiner, 1991; Delumeau et al., 1991; MacVicar et al., 1991) are increased by removing external $\mathrm{Na}^{+}$. Stimulus-evoked increases in $\left[\mathrm{Ca}^{2+}\right]_{\text {cyl }}$ are also augmented when the $\mathrm{Na}^{+}$gradient is reduced (Cornell-Bell et al., 1990; Jensen and Chiu, 1990; Blaustein et al., 1991; CornellBell and Finkbeiner, 1991). The effects of $\mathrm{Na}^{+}$gradient reduction on $\left[\mathrm{Ca}^{2+}\right]_{\text {cyt }}$ are often small, however, and this has raised questions about the role of the $\mathrm{Na} / \mathrm{Ca}$ exchanger in astrocytes (Jensen and Chiu, 1990).

In the present study, we used immunocytochemical methods to demonstrate, directly, the presence of an $\mathrm{Na} / \mathrm{Ca}$ exchanger in cultured postnatal rat cortical astrocytes. We also employed computer assisted imaging of fura- 2 fluorescence to examine the regulation of $\left[\mathrm{Ca}^{2+}\right]_{\mathrm{cyt}}$ in these cells. Our results indicate that the plasmalemmal $\mathrm{Na} / \mathrm{Ca}$ exchanger is present in astrocytes and that it may play an important role in $\mathrm{Ca}^{2+}$ transport across the plasmalemma and in the regulation of ER $\mathrm{Ca}^{2+}$ stores.

\section{Materials and Methods}

Astrocyte cultures. Primary astrocyte cultures were prepared using a modification of the method of Booher and Sensenbrenner (1972). Cerebral hemispheres of newborn rats $(<1 \mathrm{~d}$ old) were removed, placed in minimal essential medium with $20 \%$ fetal calf serum, cleaned of meninges, and trimmed to retain the neopallium. The tissue was then minced into small $\left(1 \mathrm{~mm}^{3}\right)$ pieces, transferred to a $50 \mathrm{ml}$ round-bottomed tube, and then mechanically disrupted by vortexing $(75 \mathrm{sec})$. The cell suspension was then filtered through sterile nylon screening cloth with pores sizes of $80 \mu \mathrm{m}$ (first sieving) and $10 \mu \mathrm{m}$ (second sieving) to remove blood vessels and aggregated cells. The cell suspension was not digested with enzymes. The volume of the filtered cell suspension was then adjusted with medium ( $9 \mathrm{ml} / \mathrm{brain}$ ) containing $10 \%$ fetal calf serum and seeded on $25 \mathrm{~mm}$ glass coverslips at a plating density of about 5 $\times 10^{5}$ cells per coverslip. More than $95 \%$ of the cells were GFAP+, and two types of astrocytes could be distinguished on the basis of their morphology, as described by Yarowsky and Krueger (1989): type-2 astrocytes were stellate, with round cell bodies; these cells were GFAP ${ }^{+}$ and $\mathrm{A}_{2} \mathrm{B5}^{+}$, and $\mathrm{GalC}^{-}$. Type 1 astrocytes were epithelioid in shape, and were $\mathrm{GFAP}^{+}$, and $\mathrm{A}_{25 \mathrm{~B}^{-}}$and $\mathrm{GalC}^{-}$. Type 2 astrocytes sat on top of type 1 astrocytes, and accounted for fewer than $10 \%$ of the cells in these low-density cultures. The data described in this report all refer to type 1 astrocytes; comparable effects were observed, however, in type 2 astrocytes.

Fluorescent dye loading. Astrocyles, cultured on coverslips for 6-8 d, were loaded with the $\mathrm{Ca}^{2+}$-sensitive fluorescent dye fura-2, by incubating them for $45 \mathrm{~min}$ at $20-22^{\circ} \mathrm{C}$ in medium containing $5 \mu \mathrm{M}$ fura2/AM (the membrane-permeable acetoxymethyl ester). The coverslips were then transferred to a tissue chamber mounted on a microscope stage where they were superfused for 20-30 min with PSS to wash away the extracellular dye before study. The imaging experiments were carried out at $32-34^{\circ} \mathrm{C}$.

Determination of $\left[\mathrm{Ca}^{+}\right]_{\text {.x. }}$. Details of the methods used in this study have been published (Goldman et al., 1990; Goldman, 1991). Briefly, fura-2 fluorescence $(510 \mathrm{~nm}$ emission excited by 380 and $360 \mathrm{~nm}$ illumination) from astrocytes, as well as background fluorescence, was imaged using a Nikon Diaphot inverted microscope equipped for epifluorescence microscopy. Video frames containing images of fura- 2 fluorescence and the corresponding background images (fluorescence after removing cells from the field) were digitized using an Imaging Technology (Woburn, MA) series 151 image processor operating with an Everex 386 microcomputer. Normally, 32 consecutive video frames were averaged at video frame rates to improve the signal-to-noise ratio.
The $380: 360 \mathrm{~nm}$ fluorescence ratios of fura-2-loaded astrocytes were then calculated and calibrated to express $\left[\mathrm{Ca}^{2+}\right]_{\text {cyt }}$ (Goldman et al., 1990). To simplify interpretation of the data, $\left[\mathrm{Ca}^{2+}\right]_{\mathrm{cyt}}$ measurements were limited to non-nuclear areas.

In a few experiments a Real Time Disk System (Applied Memory Technology, Tustin, CA) was used to acquire images at video frame rates $(30$ frames $/ \mathrm{sec})$. This enabled us to measure changes in $\left[\mathrm{Ca}^{2+}\right]_{\mathrm{cyt}}$ with a temporal resolution of $33 \mathrm{msec}$. Ratio images $(380: 360 \mathrm{~nm}$ ) were calculated using background-subtracted $380 \mathrm{~nm}$ images acquired during exposures to low $\mathrm{Na}^{+}$lasting several seconds and $360 \mathrm{~nm}$ images acquired immediately before and after the periods in low $\mathrm{Na}^{+}$. The latter $360 \mathrm{~nm}$ images were also used to verify that there was no significant change in dye signal or artifactual microscope movement during the exposure to low $\mathrm{Na}^{+}$(Goldman et al., 1990).

Materials and solutions for imaging experiments. Fura-2/AM was obtained from Molecular Probes (Eugene, OR). Thapsigargin (TG) was purchased from LC Services (Woburn, MA). $N$-methyl-D-glucamine (NMDG), dimethylsulfoxide (DMSO), ouabain, and 5-HT (5-hydroxytryptamine) were purchased from Sigma (St. Louis, MO). All other reagents were analytical grade or the highest purity available.

The standard physiological salt solution (PSS) contained (in $\mathrm{mm}$ ) $\mathrm{NaCl}, 140 ; \mathrm{KCl}, 5.9 ; \mathrm{NaH}_{2} \mathrm{PO}_{4}, 1.2 ; \mathrm{NaHCO}_{3}, 5 ; \mathrm{MgCl}_{2}, 1.4 ; \mathrm{CaCl}_{2}$, 1.8; glucose, 11.5; and HEPES, 10 (titrated to $\mathrm{pH} 7.4$ with $\mathrm{NaOH}$ ). Although the principal buffer was $\mathrm{HEPES}, \mathrm{NaHCO}_{3}$ was included to sustain cellular $\mathrm{HCO}_{3}$-dependent $\mathrm{pH}$ regulatory mechanisms (Boyarsky et al., 1993). For $\mathrm{Ca}^{2+}$-free solutions the $\mathrm{CaCl}_{2}$ was replaced by $1.8 \mathrm{~mm}$ $\mathrm{MgCl}_{2}$ (total of $3.2 \mathrm{~mm}$ ) and $0.5 \mathrm{~mm}$ EGTA was added. In the low- $\mathrm{Na}^{+}$ (NMG) medium, the $\mathrm{NaCl}$, was isosmotically replaced by $N$-methyl-Dglucamine (NMG), and $\mathrm{pH}$ was adjusted with $\mathrm{HCl}$. Stock solutions containing $10 \mathrm{~mm}$ fura-2/AM were prepared in DMSO.

Membrane isolation from cultured astrocytes. Cultured astrocytes were washed with PBS (phosphate-buffered saline: $120 \mathrm{~mm} \mathrm{NaCl}$ and $2.7 \mathrm{~mm}$ $\mathrm{KCl}$, in $10 \mathrm{~mm}$ Na-phosphate buffer, $\mathrm{pH}$ 7.4). The cells were scraped into PBS ( $2 \mathrm{ml}$ per $100 \mathrm{~mm}$ dish), and centrifuged at $3500 \mathrm{rpm}$ in an SS-34 rotor (Sorvall RC-5B centrifuge, DuPont, Wilmington, DE). This and all subsequent preparative steps were carried out at $4^{\circ} \mathrm{C}$. The pellet was resuspended in $10 \mathrm{~mm}$ HEPES-KOH, $\mathrm{pH} 7.0$, containing $1 \mathrm{~mm}$ dithiothreitol (DTT) and $100 \mu \mathrm{M}$ phenylmethylsulfonyl fluoride (PMSF). The suspension was gently stirred for $10 \mathrm{~min}$ at $4^{\circ} \mathrm{C}$ and then homogenized with a Polytron (Brinkmann, Westbury, NY) for $10 \mathrm{sec}$ at 7000 rpm. Sucrose was then added to the homogenate to a final concentration of $250 \mathrm{mM}$, and the homogenate was centrifuged at $7000 \times \mathrm{g}$ for 10 min. The supernatant containing microsomal membranes was collected and centrifuged at 35,000 rpm in a Beckman L5-50 ultracentrifuge (70.1 Ti rotor) for $30 \mathrm{~min}$. The pelleted microsomal membranes were used for immunoblotting. Protein concentrations were determined by the BCA protein assay reagent (Pierce, Rockford, IL), using bovine serum albumin (BSA) as a standard.

Synaptic plasma membranes (SPM) were prepared from the brains of freshly sacrificed Sprague-Dawley rats, as described by Salvaterra and Matthews (1980). Canine cardiac sarcolemmal membranes (Ambesi et al., 1991b) were generously supplied by Dr. G. Lindenmayer.

Immunoblotting. Proteins were solubilized in SDS buffer containing $20 \mathrm{~mm}$ dithiothreitol for $10 \mathrm{~min}$ at room temperature. Proteins were separated by sodium dodecyl sulfate-polyacrylamide gel electrophoresis (SDS-PAGE). The gel was calibrated with prestained protein molecular weight markers (Bio-Rad, Richmond, CA). Proteins were then transferred to a Nitro-Bind nitrocellulose membrane (MSI, Westboro, MA) as described by Towbin and Gordon (1984). The extent of transfer was checked by Ponceau-S staining. Membranes were blocked with $5 \%$ BSA in TBST (Tris-buffered saline with $0.1 \%$ Tween 20 ) for $6 \mathrm{hr}$ at room temperature. The blots were then incubated overnight at room temperature with either preimmune serum or polyclonal antibodies (1:500 dilution in TBST) raised against the purified dog cardiac sarcolemmal $\mathrm{Na} / \mathrm{Ca}$ exchanger (Ambesi et al., $1991 \mathrm{a}, \mathrm{b}$ ). The membranes were washed and incubated for $2 \mathrm{hr}$ in TBST containing $0.25 \mu \mathrm{Ci} / \mathrm{ml}{ }^{125} \mathrm{I}$-labeled Protein A (Amersham, Arlington Heights, IL), washed again, and exposed to Kodak (Rochester, NY) X-Omat film.

RNA blotting. Total RNA was prepared from cultured rat cortical astrocytes and from rat heart and brain as described (Chomczynski and Sacchi, 1987). Samples were electrophoresed for $3 \mathrm{hr}$ at $90 \mathrm{~V}$ on a $1 \%$ agarose $/ 6 \%$ formaldehyde gel, transferred to Nitro-Pure nitrocellulose membranes (MSI, Westboro, MA), and hybridized to a ${ }^{32}$-labeled probe. The gel was calibrated with a $0.24-9.5 \mathrm{~kb}$ RNA ladder (GIBCO-Bethesda Research Labs, Gaithersburg, MD). The 800 bp cDNA insert 

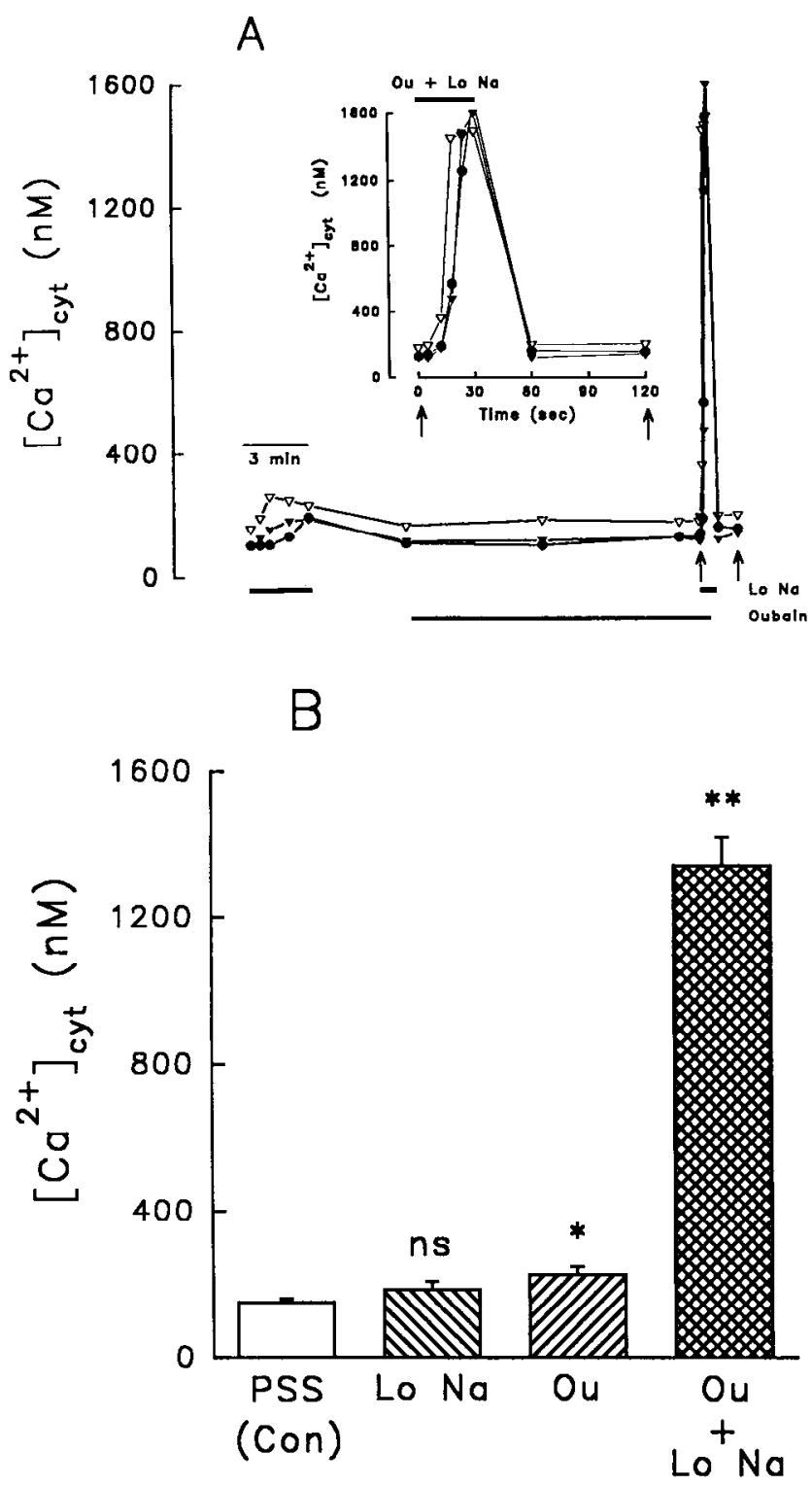

Figure 1. Effects of $\left[\mathrm{Na}^{+}\right]_{o}$ reduction and of ouabain on $\left[\mathrm{Ca}^{2+}\right]_{\mathrm{cy}}$ in unstimulated (resting) cultured rat cortical astrocytes. $A$, Time course of changes in $\left[\mathrm{Ca}^{2+}\right]_{\text {cyt }}$ for three astrocytes (each represented by a different symbol) in the same field. The cells were preloaded with fura-2 and incubated in PSS for 25 min prior to the beginning of this record. In the main graph, reduction of $\left[\mathrm{Na}^{+}\right]_{o}$ by replacing $\mathrm{NaCl}$ with $\mathrm{NMG}$, and addition of $1 \mathrm{~mm}$ ouabain, are indicated by the horizontal bars below the graph. The inset shows the rapid response to low $\left[\mathrm{Na}^{+}\right]_{o}$ in the presence of ouabain (delineated by the vertical arrows) on an expanded time scale. $B$, Composite data from a number of experiments similar to the one in $A$, showing $\left[\mathrm{Ca}^{2+}\right]_{\mathrm{cy}}$ in astrocytes incubated in the control physiological salt solution [PSS (Con); 98 cells from 18 preparations], in low- $\mathrm{Na}^{+}$medium with $\left[\mathrm{Na}^{+}\right]_{o}=6.2 \mathrm{mM}$ ( $L o \mathrm{Na} ; 38$ cells from eight preparations), in PSS containing $1 \mathrm{~mm}$ ouabain for $15 \mathrm{~min}(\mathrm{Ou} ; 80$ cells from 16 preparations), or transferred to low- $\mathrm{Na}^{+}$medium after a 15 min incubation in PSS containing $1 \mathrm{~mm}$ ouabain $(\mathrm{Ou}+\mathrm{Lo} \mathrm{Na}$; 58 cells from 12 preparations). Error bars indicate SE. $n s$, not significantly different from control; ${ }^{*}, p<0.01$ versus control; ${ }^{* *}, p<0.001$ versus control, Lo Na, and $\mathrm{Ou}$.

corresponding to the $3^{\prime}$ coding sequence of the rat heart $\mathrm{Na} / \mathrm{Ca}$ exchanger (Kofuji et al., 1992) was labeled with $\mathrm{dCT}^{32} \mathrm{P}$ by nick translation. Filters were prehybridized for a minimum of $6 \mathrm{hr}$ at $42^{\circ} \mathrm{C}$ in hybridization buffer [ $50 \%$ deionized formamide, $5 \times$ standard saline citrate (SSC), $5 \times$ Denhardt's solution, $0.5 \%$ SDS, $100 \mu \mathrm{g} / \mathrm{ml}$ denatured salmon sperm
DNA] (Maniatis et al., 1982). Following hybridization with the cDNA probe for $16 \mathrm{hr}$ at $42^{\circ} \mathrm{C}$, the filters were washed using medium-stringency conditions $\left(0.1 \times \mathrm{SSC}\right.$ at $\left.37^{\circ} \mathrm{C}\right)$ and exposed to Kodak X-Omat film.

Immunofluorescence microscopy. The cultures were grown on $12 \mathrm{~mm}$ coverslips. The astrocytes were used for experiments $7 \mathrm{~d}$ after plating. The coverslips were rinsed in L15 medium, fixed in $4 \%$ paraformal-

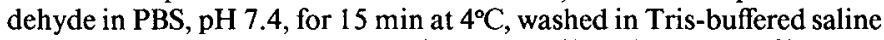
(TBS: $150 \mathrm{~mm} \mathrm{NaCl}, 100 \mathrm{~mm}$ Tris- $\mathrm{HCl}, 0.1 \% \mathrm{BSA}$, and $0.02 \% \mathrm{NaN}_{3}$, pH 7.2 , at $4^{\circ} \mathrm{C}$ ), and then permeabilized in $0.2 \%$ Triton X-100 in TBS for $15 \mathrm{~min}$ at $4^{\circ} \mathrm{C}$. Nonspecific labeling was blocked by incubating the samples for $30 \mathrm{~min}$ in 10\% normal donkey or goat serum (Jackson Immunoresearch, West Grove, PA) in TBS. An aliquot of affinity-purified polyclonal antibodies raised against the $\mathrm{Na} / \mathrm{Ca}$ exchanger (Ambesi et al., 1991a; Juhaszova et al., 1994) was diluted 1:500 in TBS and applied to the coverslips for $17 \mathrm{hr}$ at $4^{\circ} \mathrm{C}$. The coverslips were then washed $3 \times 5 \mathrm{~min}$ in TBS and labeled with FITC-conjugated, affinitypurified donkey anti-rabbit IgG, Fab $b_{2}$ fragment (Jackson Immunoresearch) at 1:100 dilution in TBS. The coverslips were washed in TBS and mounted in Citifluor (City University, London, UK) to inhibit bleaching. The specimens were examined with an Olympus BH2 fluorescence microscope (Olympus Corp., Lake Success, NY) and photographed with Kodak TMAX 3200 film.

Statistical analysis and data presentation. Numerical data are presented as means $\pm \mathrm{SE}$ of $n$ single cells from one or more independent experiments. Where appropriate, Student's $t$ test for paired or unpaired data was used to calculate the significance of the differences of the means.

\section{Results}

Intracellular $\mathrm{Ca}^{2+}$ in unstimulated astrocytes: effects of ouabain and of low $\left[\mathrm{Na}^{+}\right]_{0}$

The mean intracellular free $\mathrm{Ca}^{2+}$ concentration $\left(\left[\mathrm{Ca}^{2+}\right]_{c y}\right)$ in the non-nuclear regions of unstimulated cortical astrocytes was 153 $\pm 10 \mathrm{nM}$, with a range of $85-220 \mathrm{nM}$ (Fig. 1). These $\left[\mathrm{Ca}^{2+}\right]_{\mathrm{cyt}}$ values are comparable to those obtained in some laboratories (e.g., MacVicar et al., 1991), albeit somewhat higher than those reported by others (e.g., Jensen and Chiu, 1990; Charles et al., 1991).

A common and convenient test for the presence of a plasmalemmal $\mathrm{Na} / \mathrm{Ca}$ exchanger is to determine the effect of raising the cytosolic $\mathrm{Na}^{+}$concentration $\left(\left[\mathrm{Na}^{+}\right]_{\text {cyy }}\right)$ (e.g., with ouabain), or of lowering the external $\mathrm{Na}^{+}$concentration $\left(\left[\mathrm{Na}^{+}\right]_{o}\right)$, on resting $\left[\mathrm{Ca}^{2+}\right]_{\mathrm{cy}}$. The effects of these manipulations on cortical astrocytes are illustrated in Figure 1. Time course data for three cells from a representative experiment are shown in Figure $1 A$, and composite results from a number of similar experiments are summarized in Figure $1 B$. Reduction of $\left[\mathrm{Na}^{+}\right]_{\nu}$ from 146.2 $\mathrm{mM}$ to $6.2 \mathrm{mM}$ (using NMG as a replacement) increased $\left[\mathrm{Ca}^{2+}\right]_{\mathrm{cyt}}$ only to $185 \pm 21 \mathrm{~nm}$ on average, an insignificant rise. Exposure to $1 \mathrm{~mm}$ ouabain for $15 \mathrm{~min}$ did significantly increase $\left[\mathrm{Ca}^{2+}\right]_{\mathrm{cyt}}$, but only to $235 \pm 23 \mathrm{nM}$.

These minimal effects of transplasmalemmal $\mathrm{Na}^{+}$gradient reduction on $\left[\mathrm{Ca}^{2+}\right]_{c y t}$ have raised doubts about the contribution of $\mathrm{Na} / \mathrm{Ca}$ exchange to $\mathrm{Ca}^{2+}$ homeostasis in astrocytes (Jensen and Chiu, 1990). Often overlooked, however, is the fact that a very large fraction (>99.9\%) of the intracellular $\mathrm{Ca}^{2+}$ in most cells is buffered and/or sequestered (Blaustein, 1993; Fontana and Blaustein, 1993). Thus, large reductions in the $\mathrm{Na}^{+}$electrochemical gradient might, in fact, promote substantial net gain of $\mathrm{Ca}^{2+}$, but less than $0.1 \%$ of this $\mathrm{Ca}^{2+}$ would be expected to appear as free $\mathrm{Ca}^{2+}$ unless the $\mathrm{Ca}^{3+}$ buffer systems arc overwhelmed. Therefore, we attempted to challenge the astrocytes with an even larger change in the $\mathrm{Na}^{+}$electrochemical gradient. Following a $15 \mathrm{~min}$ exposure to $1 \mathrm{~mm}$ ouabain, the reduction of $\left[\mathrm{Na}^{+}\right]_{o}$ resulted in a rapid, very large rise in $\left[\mathrm{Ca}^{2+}\right]_{\mathrm{cyt}}$ (Fig. $1 A$ ), to a mean of $1293 \pm 29 \mathrm{~nm}$ (Fig. $1 B$ ). In mouse astrocytes, $1 \mathrm{~mm}$ ouabain reduces the $\mathrm{Na}^{+}$electrochemical gradient by 


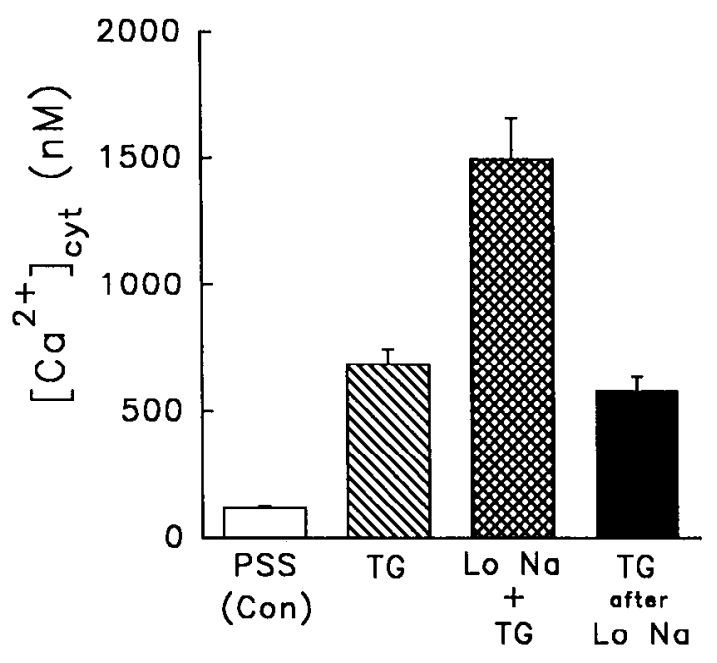

Figure 2. Effects of thapsigargin $(T G ; 30 \mathrm{nM})$ and subsequent reduction of $\left[\mathrm{Na}^{+}\right]_{o}$ to $6.2 \mathrm{~mm}$ on steady $\left[\mathrm{Ca}^{2+}\right]_{\mathrm{cy} 1}$. Following introduction of $\mathrm{TG}$, $\left[\mathrm{Ca}^{2+}\right]_{\mathrm{cyt}}$ rose to a peak and then declined to the steady level indicated by the bar labeled $T G$. Upon reduction of $\left[\mathrm{Na}^{+}\right]_{o},\left[\mathrm{Ca}^{2+}\right]_{\mathrm{yy} 1}$ rose to a new steady level $(\mathrm{Lo} \mathrm{Na}+\mathrm{TG})$. $\left[\mathrm{Ca}^{2+}\right]_{\mathrm{cyt}}$ then declined when external $\mathrm{Na}^{+}$was added back ( $T G$ after $L o \mathrm{Na}$ ). The data are from a representative experiment and correspond to the means ( \pm SE) from six cells. Con, PSS control.

increasing $\left[\mathrm{Na}^{+}\right]_{\mathrm{cyt}}$ (by about $1 \mathrm{~mm} / \mathrm{min}$; Golovina et al., 1994) and depolarizing the cells (by about $1.2 \mathrm{mV} / \mathrm{min}$; Walz, 1992). In preliminary experiments, we confirmed that $1 \mathrm{~mm}$ ouabain causes a similar depolarization of cultured rat astrocytes.

The data in Figure 2 support the view that the low- $\left[\mathrm{Na}^{+}\right]_{o^{-}}$ induced rise in $\left[\mathrm{Ca}^{2+}\right]_{\text {cyt }}$ is normally attenuated by intracellular $\mathrm{Ca}^{2+}$ sequestration in the ER. When $30 \mathrm{~nm}$ thapsigargin (TG), an ER $\mathrm{Ca}^{2+}$ pump inhibitor (Thastrup et al., 1990), was added to the superfusion fluid, $\left[\mathrm{Ca}^{2+}\right]_{\mathrm{cy}}$ rose to a peak and then declined to a new, elevated steady level, presumably because of uncompensated leak of $\mathrm{Ca}^{2+}$ from the ER and increased plasmalemmal $\mathrm{Ca}^{2+}$ permeability (Takemura et al., 1989; Baro and Eisner, 1992; Parekh et al., 1993; Randriamampita and Tsien, 1993). With $\mathrm{Ca}^{2+}$ sequestration blocked, reduction of $\left[\mathrm{Na}^{+}\right]_{o}$ in the absence of ouabain induced a further rise in $\left[\mathrm{Ca}^{2+}\right]_{\text {cyt }}$ that was significantly larger than under control conditions (sec Fig. 1).

This low- $\left[\mathrm{Na}^{+}\right]_{0}$-induced increase in $\left[\mathrm{Ca}^{2+}\right]_{\mathrm{cy} 1}$ was not a transient response. $\left[\mathrm{Ca}^{2+}\right]_{\text {cyt }}$ rose rapidly $(<0.2 \mathrm{sec}$; Fig. $3 A)$, and generally remained elevated in the low- $\mathrm{Na}^{+}$media (Fig. $3 B$ ), in contrast to the transient $\mathrm{Ca}^{2+}$ responses observed with glutamate (Fig. 12 in Blaustein et al., 1991b). Furthermore, $\left[\mathrm{Ca}^{2+}\right]_{\text {cyt }}$ declined rapidly $(<0.2 \mathrm{sec})$ if the external $\mathrm{Na}^{+}$was reintroduced within a few min (Fig. $3 A, B$; see also Fig. $1 A$ ).

\section{Dependence of the low- $\left[\mathrm{Na}^{+}\right]_{0}$-evoked rise in $\left[\mathrm{Ca}^{2+}\right]_{c y}$ on $\mathrm{Ca}^{2+}$ influx and $\mathrm{Ca}^{2+}$ release from intracellular stores}

The low- $\left[\mathrm{Na}^{+}\right]_{o}$-induced rise in $\left[\mathrm{Ca}^{2+}\right]_{\text {cyt }}$ was eliminated by removal of external $\mathrm{Ca}^{2+}$ (Fig. 4). It was not blocked, however, by the L-type $\mathrm{Ca}^{2+}$ channel blocker verapamil $(10 \mu \mathrm{M}$; not shown), which completely blocks the $\mathrm{Ca}^{2+}$ entry induced by $\mathrm{K}^{+}$depolarization in mouse astrocytes (V. A. Golovina, personal communication). Thus, even in astrocytes depolarized by ouabain, the low- $\left[\mathrm{Na}^{+}\right]_{o}$-induced $\mathrm{Ca}^{2+}$ entry is not mediated by $\mathrm{Ca}^{2+}$ channels. These characteristics are all consistent with the view that this external $\mathrm{Ca}^{2+}$ - and internal $\mathrm{Na}^{+}$-dependent rise in $\left[\mathrm{Ca}^{2+}\right]_{\mathrm{cyt}}$ is mediated by an $\mathrm{Na} / \mathrm{Ca}$ exchanger that can move
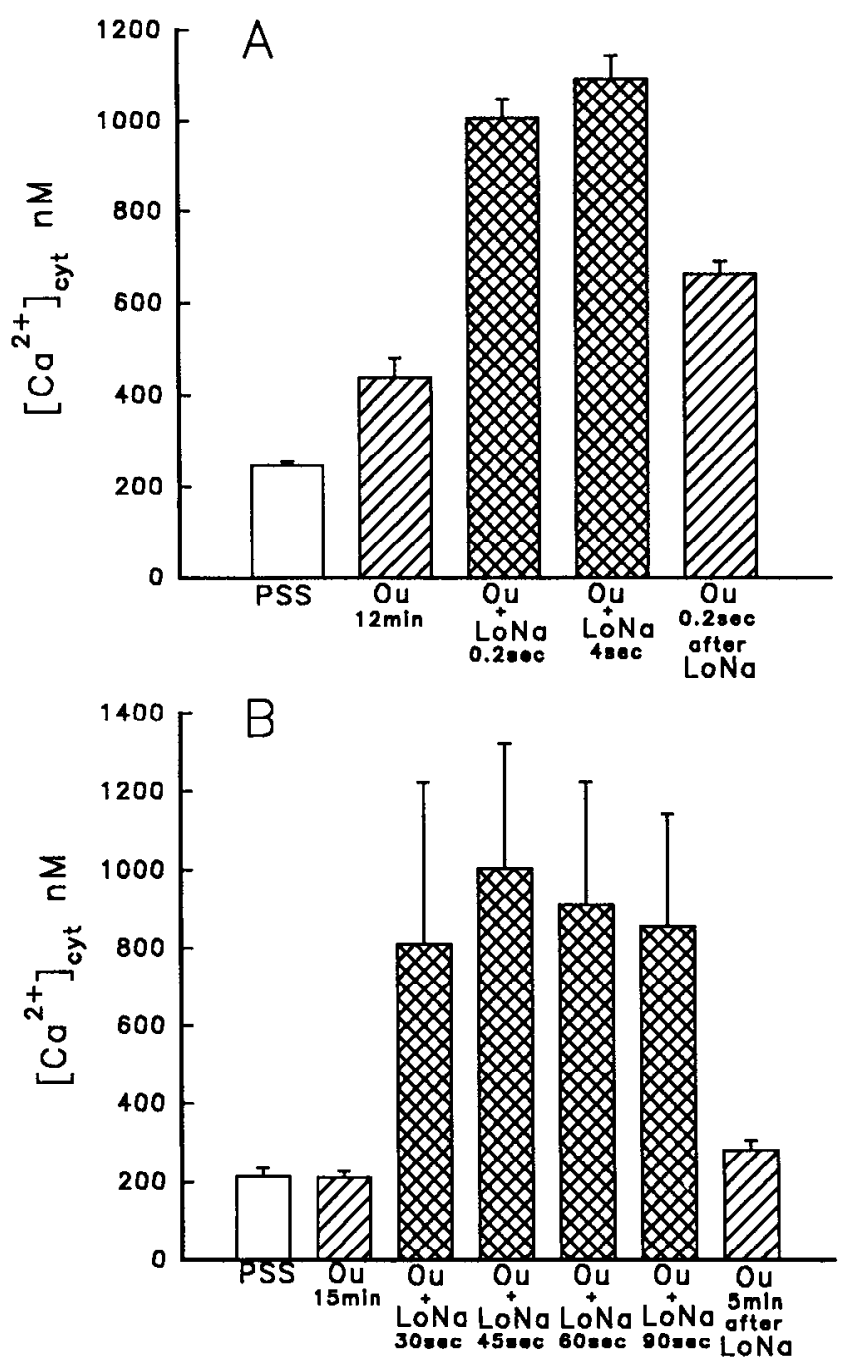

Figure 3. Time course of changes in $\left[\mathrm{Ca}^{2+}\right]_{\mathrm{cyt}}$ upon addition of $1 \mathrm{~mm}$ ouabain $(\mathrm{O} u)$ to the superfusion medium and subsequent reduction of $\left[\mathrm{Na}^{+}\right]_{o}$ to $6.2 \mathrm{~mm}$ (replacement by NMG; $L O N a$ ). $A$, Rapid time course data from an experiment in which the Real Time Disk system was used to record the data; four consecutive images were averaged to obtain each data point. Note that $\left[\mathrm{Ca}^{2+}\right]_{\mathrm{cyt}}$ rose rapidly $(<0.2 \mathrm{sec})$ when $\left[\mathrm{Na}^{+}\right]_{o}$ was reduced $(\mathrm{Ou}+\mathrm{LoNa})$, and recovered rapidly $(<0.2 \mathrm{sec})$ when the $\mathrm{Na}^{+}$was replaced $(\mathrm{Ou} 0.2$ sec after $\mathrm{LoNa})$. B, Slower time course, from a different experiment, using standard image acquisition methods, shows that the $\left[\mathrm{Ca}^{2+}\right]_{\mathrm{cyt}}$ elevation is sustained for at least $90 \mathrm{sec}$ in the low$\mathrm{Na}^{+}$media. The data in $A$ and $B$ correspond to the means ( \pm SE) from three and seven cells, respectively.

sufficient amounts of $\mathrm{Ca}^{2+}$ across the astrocyte plasmalemma to alter $\left[\mathrm{Ca}^{2+}\right]_{\text {cyt }}$ rapidly (Fig. $3 A$ ) and markedly, even though most of the entering $\mathrm{Ca}^{2+}$ is probably rapidly buffered (as noted above).

Whether all of this low- $\left[\mathrm{Na}^{+}\right]_{o}$-induced rise in $\left[\mathrm{Ca}^{2+}\right]_{\text {cyt }}$ was due to $\mathrm{Ca}^{2+}$ entry, or whether some $\mathrm{Ca}^{2+}$ was also derived from the $\mathrm{Ca}^{2+}$ stores in the ER-perhaps via $\mathrm{Ca}^{2+}$-induced $\mathrm{Ca}^{2+}$ release (CICR) - is not clear from the preceding experiments. The fact that TG, either in the absence (Fig. 2) or in the presence of ouabain (not shown), does not prevent the rise in $\left[\mathrm{Ca}^{2+}\right]_{\text {cyt }}$ in response to low $\left[\mathrm{Na}^{+}\right]_{o}$ indicates that the TG-sensitive (and $\mathrm{IP}_{3}-$ releasable) $\mathrm{Ca}^{2+}$ store is not the source of this $\mathrm{Ca}^{2+}$. Figure 5 shows that the low-[ $\left.\mathrm{Na}^{+}\right]_{0}$-induced rise in $\left[\mathrm{Ca}^{2+}\right]_{\text {cyt }}$ also is not due to CICR from a caffeine- and ryanodine-sensitive $\mathrm{Ca}^{2+}$ 


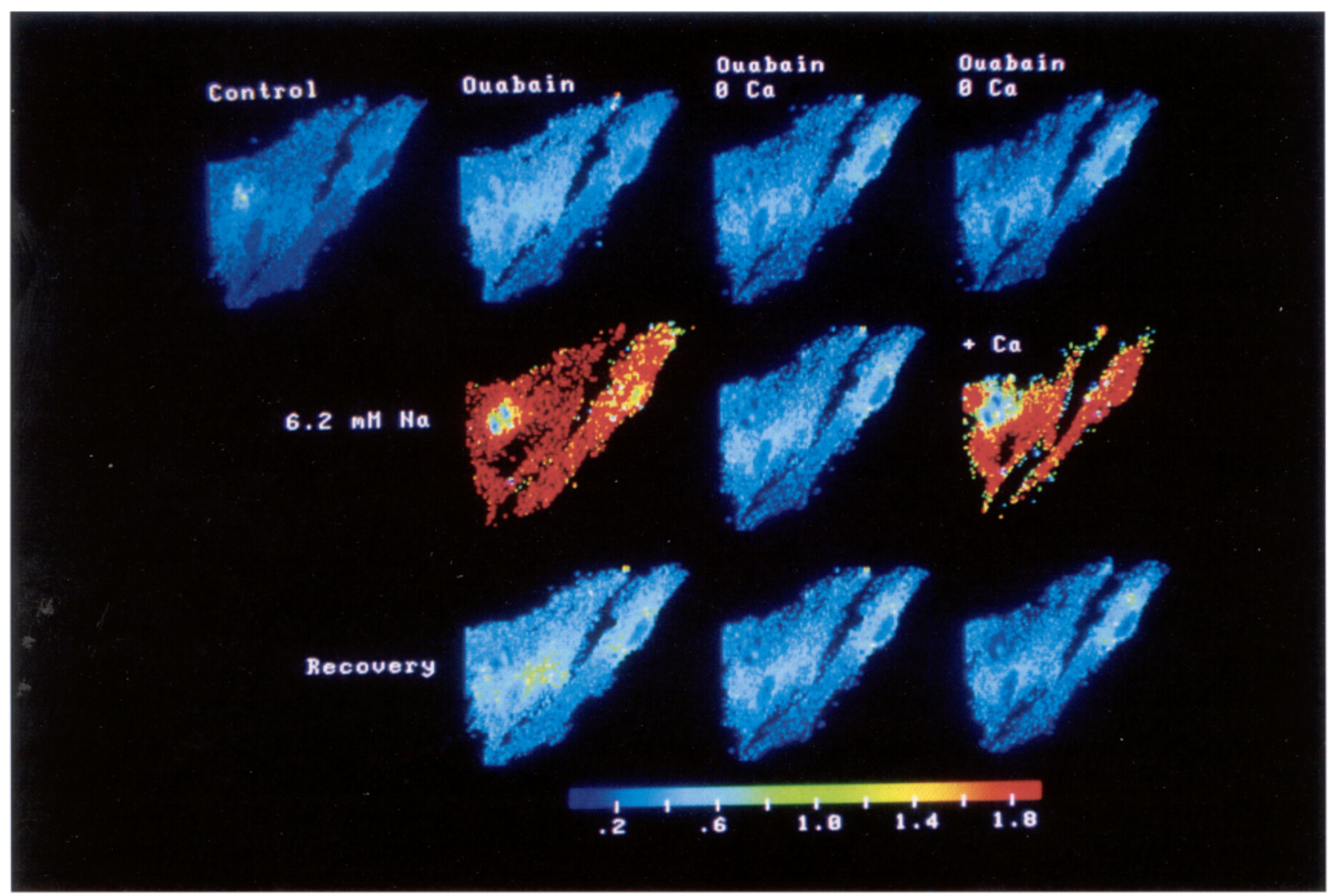

Figure 4. Pseudocolor images showing the changes in $\left[\mathrm{Ca}^{2+}\right]_{\mathrm{cyt}}$ in two astrocytes in response to ouabain, and subsequent reduction of $\left[\mathrm{Na}^{+}\right]_{o}$ in the presence and absence of external $\mathrm{Ca}^{2+}$. A $15 \mathrm{~min}$ incubation in PSS containing $1 \mathrm{~mm}$ ouabain raised $\left[\mathrm{Ca}^{2+}\right]_{\mathrm{cy}_{4}}$ only slightly (column 2 , top). Subsequent, brief reduction of $\left[\mathrm{Na}^{+}\right]_{o}$ markedly and reversibly increased $\left[\mathrm{Ca}^{2+}\right]_{\text {cyt }}$ in the presence of external Ca ${ }^{2+}($ columns 2 and 4$)$, but not in its absence (column 3). The scale at the bottom indicates the calculated free $\mathrm{Ca}^{2+}$ concentration $(\mu \mathrm{M})$.

store: a large rise in $\left[\mathrm{Ca}^{2+}\right]_{\mathrm{cyt}}$ was observed in the presence of either $10 \mathrm{~mm}$ caffeine (Fig. $5 A$ ) or $10 \mu \mathrm{M}$ ryanodine (Fig. $5 B$ ). Thus, most of the low- $\left[\mathrm{Na}^{+}\right]_{o}$-induced rise in $\left[\mathrm{Ca}^{2+}\right]_{\mathrm{cy}}$ is due to $\mathrm{Ca}^{2+}$ entry from the extracellular fluid, and does not come from intracellular $\mathrm{Ca}^{2+}$ stores.

\section{Anomalous behavior of cells with a high resting $\left[\mathrm{Ca}^{2+}\right]_{c y t}$}

The cells in two preparations did not conform to the pattern described above. In these instances (Fig. 6), the control, resting $\left[\mathrm{Ca}^{2+}\right]_{\text {cyt }}$ in all cells was substantially higher than in any of the other 18 preparations tested (Fig. 1): $338 \pm 14 \mathrm{~nm}$ in one experiment (Fig. $6 A$ ), and $555 \pm 23 \mathrm{~nm}$ in the other (Fig. $6 B$ ). Under these conditions of increased $\left[\mathrm{Ca}^{2+}\right]_{\text {cyt }}$, we might anticipate increased $\mathrm{Ca}^{2+}$ sequestration as well. In both of these preparations, replacement of most of the external $\mathrm{Na}^{+}$by $\mathrm{NMG}$, in the absence of ouabain, caused $\left[\mathrm{Ca}^{2+}\right]_{\text {cyt }}$ to rise markedly and reversibly (Fig. 6). This suggests that the large $\left[\mathrm{Ca}^{2+}\right]_{\text {cyt }}$ response to the removal of external $\mathrm{Na}^{+}$is a consequence of prior, partial $\mathrm{Ca}^{2+}$ loading (much of it, presumably, into the ER), and is not simply due to the ouabain, per se.

\section{Identification of the astrocyte $\mathrm{Na} / \mathrm{Ca}$ exchanger protein}

The preceding observations demonstrate that reversal of the normal, inwardly directed $\mathrm{Na}^{+}$gradient rapidly drives $\mathrm{Ca}^{2+}$ into astrocytes. This physiological evidence supports the view that rat cortical astrocytes contain a plasmalemmal $\mathrm{Na} / \mathrm{Ca}$ exchang- er. To substantiate this, we probed the membrane proteins from cultured astrocytes with antiserum raised against the purified canine cardiac $\mathrm{Na} / \mathrm{Ca}$ exchanger (Ambesi et al., 1991a).

Figure 7, $A$ and $B$, shows Western blots of purified canine cardiac sarcolemmal proteins (lanes $A I$ and $B I$ ) and microsomal membrane proteins from cultured rat astrocytes (lane $A 2$ ). The polyclonal antiserum specifically cross-reacted with astrocyte membrane proteins as well as with cardiac sarcolemmal proteins of about 120 and $70 \mathrm{kDa}$. Rat brain synaptic plasma membrane peptide bands of similar molecular weight are also specifically labeled with this antiserum (Fig. 7, lane B2; see also Luther et al., 1992; Yip et al., 1992); in the experiment of Figure 7, lanes $B 1$ and $B 2$, the antiserum did not cross-react with a $70 \mathrm{kDa}$ peptide, which is believed to be a proteolytic fragment of the exchanger (Nicoll et al., 1990). The preimmune serum did not cross-react with any of these proteins (not shown; see Luther et al., 1992; Yip et al., 1992).

\section{Identification of the $\mathrm{Na} / \mathrm{Ca}$ exchanger message in astrocytes}

Figure 8 shows a Northern blot of total RNA from freshly isolated rat heart (lane 1), from cultured rat astrocytes (lane 2), and from rat brain homogenate (lane 3 ). The blot was probed with an 800 bp cDNA that codes for the $3^{\prime}$ region of the $\mathrm{Na}$ / $\mathrm{Ca}$ exchanger from rat heart (Kofuji et al., 1992). Under medium-stringency conditions, the probe hybridized to a $7 \mathrm{~kb}$ mRNA from all three rat tissues, and all of these $7 \mathrm{~kb}$ signals 


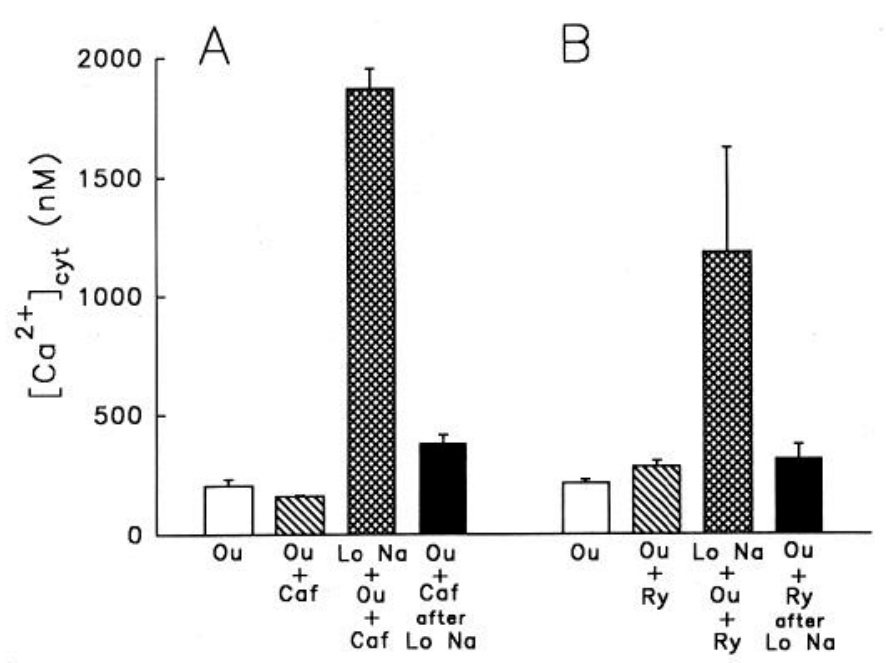

Figure 5. The effects of $\left[\mathrm{Na}^{+}\right]_{o}$ reduction (to $6.2 \mathrm{~mm}$; $\mathrm{Lo} \mathrm{Na}$ ) on $\left[\mathrm{Ca}^{2+}\right]_{\mathrm{cy}}$ in ouabain-treated astrocytes in the presence of $10 \mathrm{~mm}$ caffeine $(A, C a f)$ and $10 \mu \mathrm{M}$ ryanodine $(B, R y)$. The cells were incubated in PSS containing $1 \mathrm{~mm}$ ouabain for at least $15 \mathrm{~min}$ prior to the treatments with the $\mathrm{Ca}^{2+}$ releasing agents and exposure to the low- $\left[\mathrm{Na}^{+}\right]_{o}$ media. The recovery in PSS containing ouabain and the releasing agents $(\mathrm{Ou}+\mathrm{Caf}$ or $\mathrm{Ry}$, after $\mathrm{Lo} \mathrm{Na}$ ) is also shown. Each panel shows the responses of cells in a single preparation ( $A$, three cells; $B$, seven cells); error bars indicate $\pm \mathrm{SE}$.

were strong. In addition, the probe hybridized to smaller ( 3.5 $\mathrm{kb}$ ) and larger (about $14 \mathrm{~kb}$ ) messages from the brain. A $7 \mathrm{~kb}$ mRNA has been identified as the full-sized message that encodes the canine cardiac $\mathrm{Na} / \mathrm{Ca}$ exchanger (39); thus, our data suggest that the astrocyte exchanger is encoded by a similar-sized message. The larger and smaller messages from rat brain (also observed in human brain by Kofuji et al., 1992) may be the result of alternative splicing.

\section{Localization of the $\mathrm{Na} / \mathrm{Ca}$ exchanger in astrocytes by immunofluorescence microscopy}

These studies demonstrate that rat cortical astrocytes have an $\mathrm{Na} / \mathrm{Ca}$ exchanger that is similar in molecular size and immunological cross-reactivity to the $\mathrm{Na} / \mathrm{Ca}$ exchanger of cardiac muscle. Thus, antiserum raised against the cardiac exchanger may be used with immunofluorescence techniques to determine the distribution of the $\mathrm{Na} / \mathrm{Ca}$ exchanger in cultured astrocytes.

Affinity-purified anti- $\mathrm{Na} / \mathrm{Ca}$ exchanger antibodies (Juhaszova et al., 1994) were employed to study the distribution of the exchanger on the surfaces of astrocytes. The astrocytes in Figure $9 \mathrm{~A}$ were incubated with antibodies raised against the cardiac $\mathrm{Na} / \mathrm{Ca}$ exchanger. All cells in the cultures were labeled, and the label was distributed over the entire surface of each of the cells. The labeling pattern appears to be diffuse (unorganized) in some areas. In other areas, however, the labeling gives the appearance of strings of beads arranged in a reticular network (Fig. $9 \mathrm{~A}$, arrows). The labeling is specific, as indicated by the absence of labeling when cells are incubated with similarly prepared preimmune serum (Fig. 9B).

\section{Discussion}

\section{Astrocytes contain an $\mathrm{Na} / \mathrm{Ca}$ exchanger}

The experiments reported here demonstrate that cultured rat cortical astrocytes contain a plasmalemmal $\mathrm{Na} / \mathrm{Ca}$ exchange mechanism that can mediate rapid changes in $\left[\mathrm{Ca}^{2+}\right]_{\mathrm{cyt}}$ when

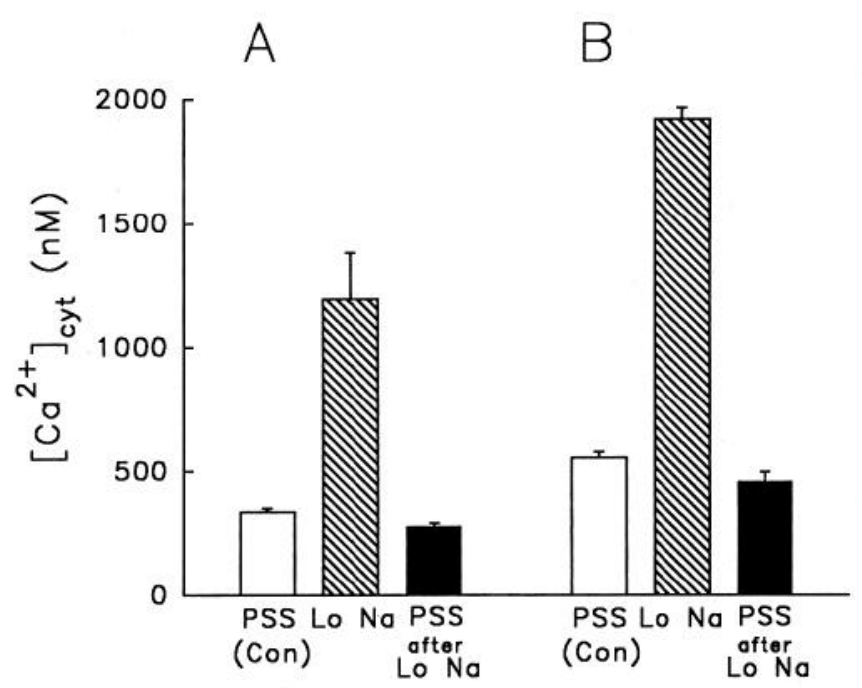

Figure 6. The effects of $\left[\mathrm{Na}^{+}\right]_{o}$ reduction $(\mathrm{Lo} \mathrm{Na})$ on $\left[\mathrm{Ca}^{2+}\right]_{\mathrm{cyt}}$ in two astrocyte preparations ( $A$, five cells; $B, 10$ cells) in which the initial resting $\left[\mathrm{Ca}^{2+}\right]_{\mathrm{cyt}}$ was unusually high (compare Fig. 1). The effects of $\left[\mathrm{Na}^{+}\right]_{o}$ reduction $(\mathrm{Lo} \mathrm{Na})$ were reversible, and $\left[\mathrm{Ca}^{2+}\right]_{\mathrm{cyt}}$ returned to the control level when external $\mathrm{Na}^{+}$was replaced (PSS after Lo Na).

the $\mathrm{Na}^{+}$electrochemical gradient is altered. In this respect, astrocytes do not differ substantially from other cell types such as neurons, cardiac myocytes, smooth muscle cells, and many epithelial cells (Blaustein et al., 1991a). A specific, rather complex protocol is required to demonstrate increased $\left[\mathrm{Ca}^{2+}\right]_{\text {cyt }}$ mediated by the $\mathrm{Na} / \mathrm{Ca}$ exchanger. This explains previous reports of failure to observe increased $\left[\mathrm{Ca}^{2+}\right]_{\mathrm{cyt}}$ induced by lowered $\left[\mathrm{Na}^{+}\right]_{o}$ alone. In order to observe a rise in $\left[\mathrm{Ca}^{2+}\right]_{\mathrm{cyt}}$, it is necessary to raise $\left[\mathrm{Na}^{+}\right]_{\text {cyt }}$ (e.g., by inhibiting the $\mathrm{Na}$ pump) and to lower

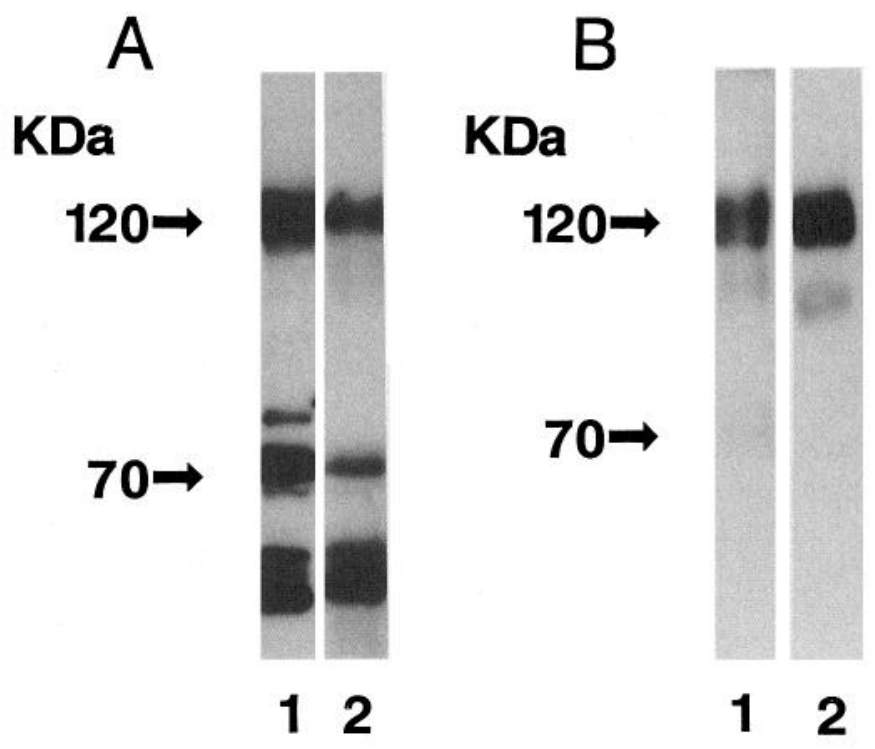

Figure 7. Western immunoblots of purified canine cardiac sarcolemmal proteins (lanes $A 1$ and $B 1 ; 5 \mu \mathrm{g}$ ), cultured rat astrocyte microsomal membrane proteins (lane $A 2 ; 100 \mu \mathrm{g} /$ lane) and rat brain synaptic plasma membrane (SPM) proteins (lane $B 2 ; 20 \mu \mathrm{g}$ ). $A$ and $B$ are from different experiments. The proteins were probed with antibodies raised against the purified canine cardiac sarcolemmal Na/Ca exchanger. The arrows at the left in $A$ and $B$ indicate the calculated positions of the 120 and $70 \mathrm{kDa}$ bands. 


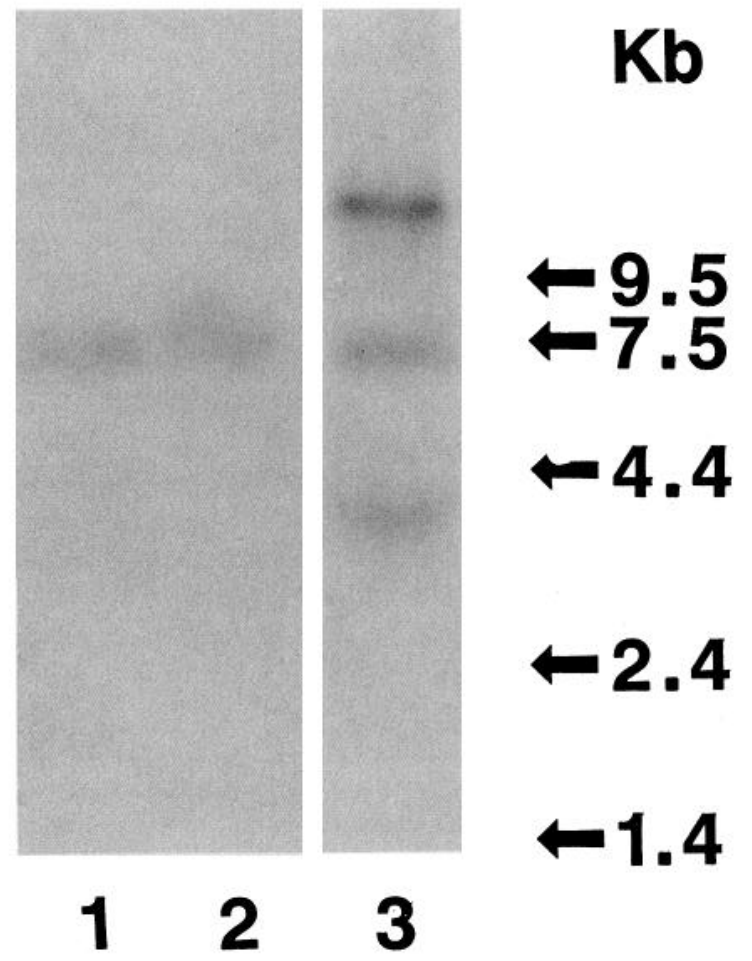

Figure 8. Northern blot of total RNA from freshly isolated rat heart (lane 1;5 $\mu \mathrm{g}$ ), cultured rat astrocytes (lane 2; $20 \mu \mathrm{g}$ ), and rat brain homogenate (lane $3 ; 20 \mu \mathrm{g}$ ). The RNA was probed with a cDNA containing 800 base pairs that codes for the $3^{\prime}$ region of the rat heart $\mathrm{Na} /$ $\mathrm{Ca}$ exchanger. The arrows at the right indicate the positions of the standards in kilobases $(K b)$.

extracellular $\left[\mathrm{Na}^{+}\right]$simultaneously. Ouabain may contribute to this effect, not only by raising $\left[\mathrm{Na}^{+}\right]_{\mathrm{cyt}}$ (Golovina et al., 1994), but also by partially depolarizing the astrocytes (Walz, 1992) and thereby lowering the $\mathrm{Na}^{+}$electrochemical gradient even further. We suggest that these maneuvers promote net $\mathrm{Ca}^{2+}$ entry via the exchanger by reducing or reversing the $\mathrm{Na}^{+}$electrochemical gradient. Kinetically, high $\left[\mathrm{Na}^{+}\right]_{\text {cyt }}$, low $\left[\mathrm{Na}^{+}\right]_{o}$, and membrane depolarization would all be expected to accelerate $\mathrm{Ca}^{2+}$ influx and reduce $\mathrm{Ca}^{2+}$ efflux. Indeed, the large rise in $\left[\mathrm{Ca}^{2+}\right]_{\mathrm{cyt}}$ caused by these maneuvers is prevented by removal of extracellular $\mathrm{Ca}^{2+}$. We emphasize that both increased $\left[\mathrm{Na}^{+}\right]_{\text {cyt }}$ and lowered $\left[\mathrm{Na}^{+}\right]_{o}$ are required for substantial increases in $\left[\mathrm{Ca}^{2+}\right]_{\text {cyi }}$; either manipulation alone is ineffective. The reason is that the ER is able to buffer most of the $\mathrm{Ca}^{2+}$ entering in response to either elevated $\left[\mathrm{Na}^{+}\right]_{\mathrm{cyt}}$ or reduced $\left[\mathrm{Na}^{+}\right]_{o}$ but is incapable of handling the very large amounts of $\mathrm{Ca}^{2+}$ entering in response to both maneuvers. This is supported by the observation that, in the presence of thapsigargin, an inhibitor of $\mathrm{Ca}^{2+}$ accumulation into $\mathrm{IP}_{3}$-sensitive intracellular stores, lowering $\left[\mathrm{Na}^{+}\right]_{o}$ induced a large increase in $\left[\mathrm{Ca}^{2+}\right]_{\mathrm{cyt}}$ similar in magnitude to that observed in the presence of ouabain.

In addition to the physiological results described above, we present biochemical evidence for the presence of an $\mathrm{Na} / \mathrm{Ca}$ exchanger in cortical astrocytes. Northern blot analysis using a probe specific for the canine heart $\mathrm{Na} / \mathrm{Ca}$ exchanger revealed a similar labeling pattern to that observed using RNA from rat heart and fetal rat brain. This suggests that $\mathrm{Na} / \mathrm{Ca}$ exchangers in astrocytes have a similar molecular structure to those in heart and neurons. This conclusion is supported by Western blot data using antibodies raised against the heart $\mathrm{Na} / \mathrm{Ca}$ exchanger; the antibody labeled similar bands in gels loaded with astrocyte, heart, and synaptic membranes. As both Northern and Western blot analyses indicate, $\mathrm{Na} / \mathrm{Ca}$ exchangers from astrocytes are very similar in molecular structure to those in neurons, cardiac myocytes, and smooth muscle cells. This class of $\mathrm{Na} / \mathrm{Ca}$ exchangers differs both structurally and functionally from the $\mathrm{Na}$ / $\mathrm{Ca}$ exchanger in photoreceptors (Reiländer et al., 1992). Fluorescence immunohistochemistry using antibodies raised against the heart $\mathrm{Na} / \mathrm{Ca}$ exchanger revealed that virtually all astrocytes were labeled; however, the label was not uniformly distributed over the cell. Rather, at least in some areas, the exchanger was localized in reticular networks, possibly following underlying cytoskeletal structures. Distribution of the $\mathrm{Na} / \mathrm{Ca}$ exchanger in similar reticular networks has been observed in smooth muscle cells, where it has been suggested that the plasmalemmal exchanger molecules may be concentrated in regions where the endoplasmic/sarcoplasmic reticulum (ER/SR) is closely apposed to the plasmalemma (Moore et al., 1993; Juhaszova et al., 1994). This may promote functional coupling between the ER/SR and the plasmalemma in terms of cell $\mathrm{Ca}^{2+}$ regulation (Blaustein, 1993; Moore and Fay, 1993).

\section{Functional coupling of $\mathrm{Na} / \mathrm{Ca}$ exchange to intracellular $\mathrm{Ca}^{2+}$ stores}

A modest reduction in the net extrusion of $\mathrm{Ca}^{2+}$ via the $\mathrm{Na} / \mathrm{Ca}$ exchanger does not substantially increase $\left[\mathrm{Ca}^{2+}\right]_{\text {cyt }}$, suggesting that much of the $\mathrm{Ca}^{2+}$ entering the cell under these conditions is accumulated in intracellular stores. The observation that TG mimics the effect of ouabain in potentiating the action of reduced $\left[\mathrm{Na}^{+}\right]_{o}$, and itself raises $\left[\mathrm{Ca}^{2+}\right]_{\mathrm{cyt}}$, suggests that an $\mathrm{IP}_{3}$-sensitive $\mathrm{Ca}^{2+}$ store is largely responsible for this $\mathrm{Ca}^{2+}$ buffering activity. Further support for this idea comes from the observation that pretreatment of mouse cortical astrocytes with ouabain, $\mathrm{K}^{+}$-free media, or reduced $\left[\mathrm{Na}^{+}\right]_{o}$ greatly potentiates the magnitude of the $\mathrm{Ca}^{2+}$ transient induced by TG or cyclopiazonic acid (Golovina et al., 1993, 1994), which block $\mathrm{Ca}^{2+}$ uptake and lead to net $\mathrm{Ca}^{2+}$ leak from $\mathrm{IP}_{3}$-sensitive stores. Thus, the initial consequence of reducing the effectiveness of $\mathrm{Ca}^{2+}$ extrusion via the $\mathrm{Na} / \mathrm{Ca}$ exchanger is loading of the intracellular stores rather than a significant rise in $\left[\mathrm{Ca}^{2+}\right]_{\mathrm{cyt}}$, which might be cytotoxic (see below).

Release of $\mathrm{Ca}^{2+}$ from intracellular stores plays a role in a variety of cellular responses, including several that have been described in rodent astrocytes (Finkbeiner, 1993). For example, many neurotransmitters, including the excitotoxin glutamate, increase $\left[\mathrm{Ca}^{2+}\right]_{\mathrm{cyt}}$ in cultured astrocytes. Any such responses involving $\mathrm{Ca}^{2+}$ release from thapsigargin- (and $\mathrm{IP}_{3}-$ ) sensitive stores should be greatly augmented when $\mathrm{Ca}^{2+}$ extrusion by the $\mathrm{Na} / \mathrm{Ca}$ exchanger is compromised. For example, we have directly demonstrated that ouabain potentiates glutamate-induced increases in $\left[\mathrm{Ca}^{2+}\right]_{\mathrm{cyt}}$ in rat astrocytes (Blaustein et al., 1991b).

Recent studies have revealed that intercellular signaling takes places between cultured astrocytes by means of transient increases in $\left[\mathrm{Ca}^{2+}\right]_{\text {cyt }}$ that propagate from cell to cell as waves of elevated $\left[\mathrm{Ca}^{2+}\right]_{\text {cyt }}$. Such $\mathrm{Ca}^{2+}$-mediated intercellular signaling may operate in parallel with the rapid interneuronal signaling mediated by action potentials and synaptic transmission. Charles et al. (1991) have demonstrated that such propagated $\mathrm{Ca}^{2+}$ waves require cyclical $\mathrm{Ca}^{2+}$ accumulation into and release from both $\mathrm{IP}_{3}$ and $\mathrm{Ca}^{2+}$-sensitive (caffeine/ryanodyne-sensitive) stores. Our 

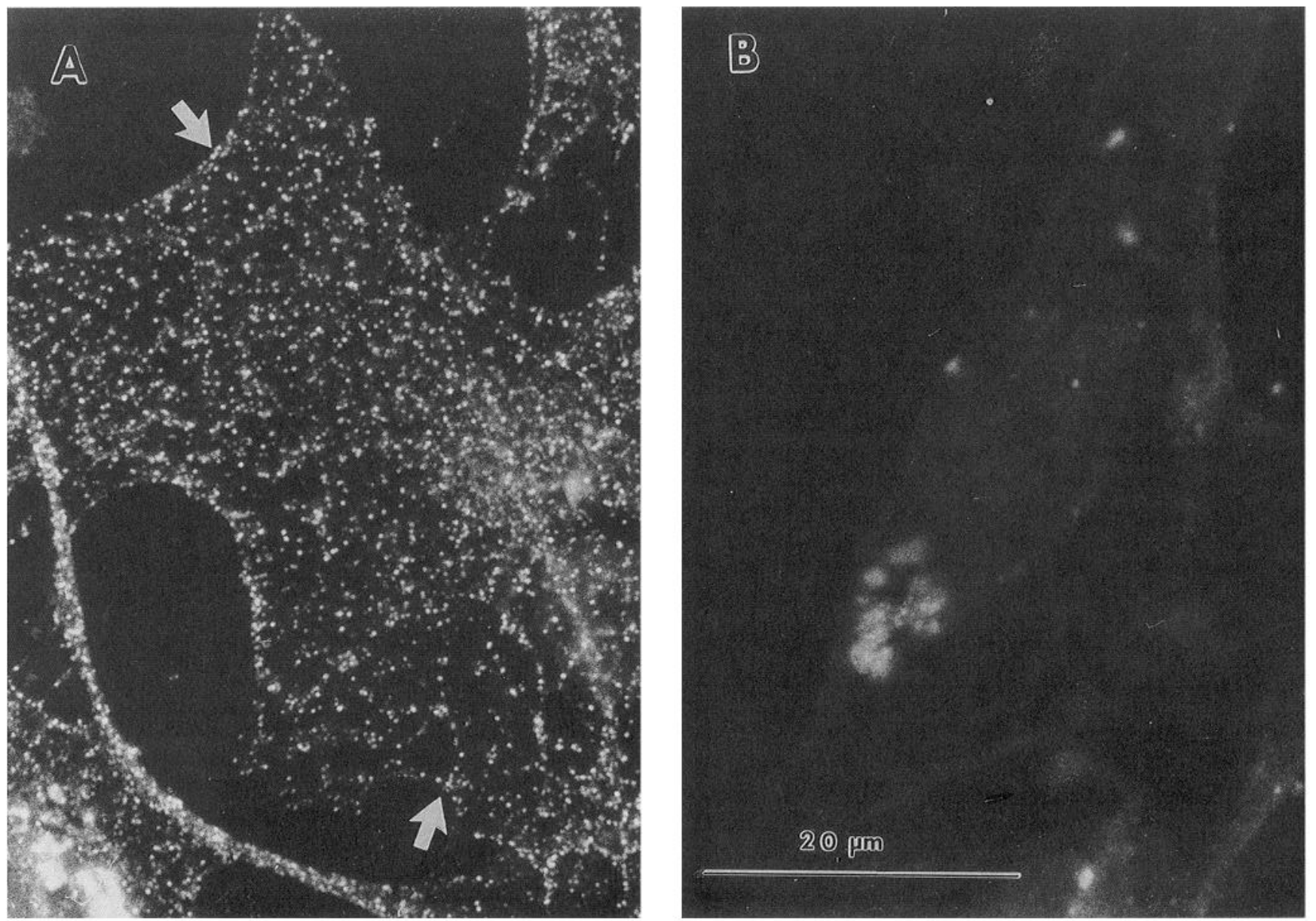

Figure 9. Immunochemical localization of $\mathrm{Na} / \mathrm{Ca}$ exchangers in cultured rat brain astrocytes. The cell in $A$ was probed with affinity-purified antibodies raised against purified canine cardiac sarcolemmal $\mathrm{Na} / \mathrm{Ca}$ exchanger. The cell in $B$ was probed with similarly prepared preimmune serum. The arrows in $A$ point to regions of the cell in which the label has a distinct reticular pattern. Scale bar (in $B$ ), $20 \mu \mathrm{m}$ (for $A$ and $B$ ).

results suggest that the efficacy of $\mathrm{Ca}^{2+}$ extrusion by the $\mathrm{Na} / \mathrm{Ca}$ exchanger might differentially affect loading of the $\mathrm{IP}_{3}$-sensitive store and thus affect properties of the propagated $\mathrm{Ca}^{2+}$ waves such as magnitude, speed, or distance traveled.

\section{Extracellular signals that might affect $\mathrm{Ca}^{2+}$ entry and loading of intracellular stores}

Our data indicate that any of a variety of conditions that affect the maintenance of the transmembrane $\mathrm{Na}^{+}$electrochemical gradient will alter the efficacy of the $\mathrm{Na} / \mathrm{Ca}$ exchanger and hence will affect both $\left[\mathrm{Ca}^{2+}\right]_{\text {cyt }}$ and the amount of $\mathrm{Ca}^{2+}$ stored in and released from intracellular organelles. Conditions that depolarize the plasma membrane (e.g., elevated $\left[\mathrm{K}^{+}\right]_{o}$ in the vicinity of active neurons) would increase net $\mathrm{Ca}^{2+}$ influx directly, by opening voltage-gated $\mathrm{Ca}^{2+}$ channels, and indirectly, by slowing $\mathrm{Ca}^{2+}$ extrusion via the (electrogenic) $\mathrm{Na} / \mathrm{Ca}$ exchanger or by increasing $\mathrm{Na}^{+}$influx though noninactivated $\mathrm{Na}^{+}$channels. Recently, ouabain has been shown to be a vertebrate adrenocortical hormone (Hamlyn et al., 1991) but ouabain itself (Yamada et al., 1992), or an analog (Tymiak et al., 1993), may also be produced and secreted in the brain. Thus, inhibition of the $\mathrm{Na}^{+}$pump by endogenous ouabain may, via its indirect effect on $\mathrm{Na} / \mathrm{Ca}$ exchange, play a physiological role in the control of intracellular $\mathrm{Ca}^{2+}$ stores in astrocytes and other brain cells.
Do astrocytes buffer $\mathrm{Ca}^{2+}$ in the extracellular space surrounding synapses?

Most central synapses are surrounded by astrocytes so that there is only a very limited extracellular space. Therefore, in view of the critical role of $\mathrm{Ca}^{2+}$ entry in neurotransmitter release (Katz, 1969), it is important to consider how the extracellular $\mathrm{Ca}^{2+}$ concentration $\left(\left[\mathrm{Ca}^{2+}\right]_{o}\right)$ is regulated in this very restricted space. Our evidence that the astrocyte $\mathrm{Na} / \mathrm{Ca}$ exchanger can transport considerable amounts of $\mathrm{Ca}^{2+}$ across the plasmalemma, in both directions, and that it can help to modulate the amount of $\mathrm{Ca}^{2+}$ in astrocyte intracellular stores, raises a new possibility. Perhaps, astrocytes can act as sources and sinks for $\mathrm{Ca}^{2+}$, so that they can help to buffer $\left[\mathrm{Ca}^{2+}\right]_{o}$ in the synaptic clefts, much as they are thought to buffer $\left[\mathrm{K}^{+}\right]_{o}$. For example, the astrocytes may extrude $\mathrm{Ca}^{2+}$ into the extracellular space when they are stimulated to release $\mathrm{Ca}^{2+}$ from intracellular stores and $\left[\mathrm{Ca}^{2+}\right]_{\mathrm{cyt}}$ rises transiently. The astrocytes may thereby help to replenish extracellular $\mathrm{Ca}^{2+}$ in the interstitial space surrounding synapses when the neurons are sufficiently active to deplete extracellular $\mathrm{Ca}^{2+}$ A related possibility is that the $\mathrm{Na} / \mathrm{Ca}$ exchanger in the astrocytes may maintain the steady-state perisynaptic $\left[\mathrm{Ca}^{2+}\right]$ at a lower level than that in the CSF in general. Thus, astrocytes, by controlling $\left[\mathrm{Ca}^{2+}\right]_{o}$, may dynamically regulate the efficacy of adjacent synapses. 


\section{Possible role of astrocyte $\mathrm{Na} / \mathrm{Ca}$ exchange system in neurodegeneration}

Rccent studics have suggestcd that $\left[\mathrm{Ca}^{2+}\right]_{\mathrm{cyt}}$ plays more than onc critical role in cell survival. The central role of elevated $\left[\mathrm{Ca}^{2+}\right]_{c y t}$ in cell death resulting from neurotoxins, ischemia, and tissue damage is well documented (Mattson et al., 1989; Stys et al., 1990; Siesjó, 1991; Choi, 1992). Indeed, it has been demonstrated that inhibition of the $\mathrm{Na}^{+}$pump by ouabain increases the susceptibility of neurons to excitotoxic death (Brines and Robbins, 1992). Thus, the failure of intracellular stores to buffer a $\mathrm{Ca}^{2+}$ load adequately (Fig. 1) when the $\mathrm{Na} / \mathrm{Ca}$ exchanger is compromised (by reducing the $\mathrm{Na}^{+}$electrochemical gradient) may be the correlate of this ouabain-induced susceptibility to excitotoxicity. In contrast, $\left[\mathrm{Ca}^{2+}\right]_{\mathrm{cyt}}$ must be maintained above a threshold level for normal cell viability. According to the $\mathrm{Ca}^{2+}$ setpoint hypothesis (Franklin and Johnson, 1992) neurons with abnormally low $\left[\mathrm{Ca}^{2+}\right]_{\text {cyt }}$, have an increased requirement for survival factors. Although astrocytes may be less sensitive than neurons to excitotoxic death induced by $\mathrm{Ca}^{2+}$ overload (Choi et al., 1987), it seems likely that, like neurons, astrocytes require that $\left[\mathrm{Ca}^{2+}\right]_{\text {cyt }}$ be maintained within a certain critical range for optimum viability and function. The $\mathrm{Na} / \mathrm{Ca}$ exchanger, coupled to releasable intracellular $\mathrm{Ca}^{2+}$ stores, is likely to play a central role in maintaining $\left[\mathrm{Ca}^{2+}\right]_{\text {cyt }}$ within this range, both in the steady state and during active signaling by both neurons and astrocytes.

\section{References}

Achilles A, Friedel U, Haase W, Reiländer H, Cook NJ (1991) Biochemical and molecular characterization of the sodium-calcium exchanger from bovine rod photoreceptors. Ann NY Acad Sci 639:234244.

Ahmed Z, Lewis CA, Faber DS (1990) Glutamate stimulates release of $\mathrm{Ca}^{2+}$ from internal stores in astroglia. Brain Res 516:165-169.

Ambesi A, Bagwell EE, Lindenmayer GE (1991a) Purification and identification of the cardiac sarcolemmal $\mathrm{Na} / \mathrm{Ca}$ exchanger. Biophys J 59:138a.

Ambesi A, VanAlystyne EL, Bagwell EE, Lindenmayer GE (1991b) Sequential use of detergents for solubilization and reconstitution of a membrane ion transporter. Anal Biochem 198:312-317.

Baro I, Eisner DA (1992) The effects of thapsigargin on $\left[\mathrm{Ca}^{2+}\right]_{i}$ in isolated rat mesenteric artery vascular smooth muscle cells. Pfiuegers Arch 420:115-117.

Barres BA (1991) New roles for glia. J Neurosci 11:3685-3694.

Barres BA, Chun LLY, Corey DP (1990) Ion channels in vertebrate glia. Annu Rev Neurosci 13:441-474.

Blaustein MP (1993) Physiological effects of endogenous ouabain: control of intracellular $\mathrm{Ca}^{2+}$ stores and cell responsiveness. Am J Physiol 264:C1367-C1387.

Blaustein MP, DiPolo R, Reeves JP, eds (1991a) Sodium-calcium exchange. Proceedings of the second international conference. Ann NY Acad Sci 639:1-667.

Blaustein MP, Goldman WF, Fontana G, Krueger BK, Santiago E, Steel TD, Weiss DN, Yarowsky PJ (1991b) Physiological roles of the sodium-calcium exchanger in nerve and muscle. Ann NY Acad Sci 639:254-274.

Booher J, Sensenbrenner M (1972) Growth and cultivation of dissociated neurons and glial cells from embryonic chick, rat and human brain in flask cultures. Neurobiology 2:97-105.

Borin ML, Goldman WF, Blaustein MP (1993) Intracellular $\mathrm{Na}^{+}$in resting and activated A7r5 vascular smooth muscle cells. Am J Physiol 264:C1513-C1524.

Bova S, Goldman WF, Yuan X-J, Blaustein MP (1990) Influence of $\mathrm{Na}^{+}$gradient on $\mathrm{Ca}^{2+}$ transients and contraction in smooth muscle. Am J Physiol 259:H409-H423.

Boyarsky G, Ransom B, Schlue, W-R, Davis MBE, Boron WF (1993) Intracellular $\mathbf{p H}$ regulation in single cultured astrocytes from rat forebrain. Glia 8:241-248.

Brines ML, Robbins RJ (1992) Inhibition of $\alpha 2 / \alpha 3$ sodium pump isoforms potentiates glutamate neurotoxicity. Brain Res 591:94-102.
Charles AC, Merrill JE, Dirksen ER, Sanderson MJ (1991) Intercellular signaling in glial cells: calcium waves and oscillations in response to mechanical stimulation and glutamate. Neuron 6:983-992.

Choi DW (1992) Excitotoxic cell death. J Neurobiol 23:1261-1276.

Choi DW, Maulucci-Gedde MA, Kriegstein AR (1987) Glutamate neurotoxicity in cortical cell culture. J Neurosci 7:357-368.

Chomczynski P, Sacchi N (1987) Single step method of RNA isolation by acid guanidinium thiocyanate-phenol-chloroform extraction. Anal Biochem 162:156-159.

Cornell-Bell AH, Finkbeiner SM (1991) $\mathbf{C a}^{2+}$ waves in astrocytes. Cell Calcium 12:185-204.

Cornell-Bell AH, Finkbeiner SM, Cooper MS, Smith S.I (1990) Glutamate induces calcium waves in cultured astrocytes: long-range glial signaling. Science 247:470-473.

Delumeau JC, Petitet F, Cordier J, Glowinski J, Prémont J (1991) Synergistic regulation of cytosolic $\mathrm{Ca}^{2+}$ concentration in mouse astrocytes by NK1 tachykinin and adenosine agonists. J Neurochem 57:2026-2035.

Finkbeiner SM (1993) Glial calcium. Glia 9:83-104.

Fontana G, Blaustein MP (1993) Calcium buffering and free $\mathrm{Ca}^{2+}$ in rat brain synaptosomes. J Neurochem 60:843-850.

Franklin JL, Johnson EM Jr (1992) Suppression of programmed neuronal death by sustained elevation of cytoplasmic calcium. Trends Neurosci 15:501-508.

Glaum SR, Holzwarth JA, Miller RJ (1990) Glutamate receptors activate $\mathrm{Ca}^{2+}$ mobilization and $\mathrm{Ca}^{2+}$ influx into astrocytes. Proc Natl Acad Sci USA 87:3454-3458.

Goldman WF (1991) Spatial and temporal resolution of serotonininduced changes in intracellular calcium in a cultured arterial smooth muscle cell line. Blood Vessels 28:252-261.

Goldman WF, Bova S, Blaustein MP (1990) Measurement of intraccllular $\mathrm{Ca}$ in culturcd artcrial smooth musclc cclls using fura-2 and digital imaging microscopy. Cell Calcium 11:221-231.

Golovina VA, Bamberg LL, Krueger BK, Yarowski PJ, Blaustein MP (1993) $\mathrm{Ca}^{2+}$ regulation in mouse cortical astrocytes: role of internal $\mathrm{Ca}^{2+}$ stores and the Na-Ca exchanger. Soc Neurosci Abstr 19:687.

Golovina VA, Bamberg LL, Krueger BK, Yarowski PJ, Blaustein MP (1994) $\mathrm{Na}-\mathrm{Ca}$ exchange regulates intracellular stores of $\mathrm{Ca}^{2+}$ in mouse cortical astrocytes. Biophys J 66:A255.

Hamlyn JM, Blaustein MP, Bova S, DuCharme DW, Harris DW, Mandel F, Mathews WR, Ludens JH (1991) Identification and characterization of a ouabain-like compound from human plasma. Proc Natl Acad Sci USA 81:6259-6263.

Jensen AM, Chiu SY (1990) Fluorescence measurement of changes in intracellular calcium induced by excitatory amino acids in cultured cortical astrocytes. J Neurosci 10:1165-1175.

Jensen AM, Chiu SY (1991) Differential intracellular calcium responses to glutamate in type 1 and type 2 cultured brain astrocytes. J Neurosci 11:1674-1684.

Juhasova M, Ambesi A, Lindenmayer GE, Bloch RJ, Blaustein MP (1994) The $\mathrm{Na} / \mathrm{Ca}$ exchanger in arteries: identification by immunoblotting and immunofluorescence microscopy. Am J Physiol 266: C234-C242.

Katz B (1969) The release of neural transmitter substances. Springfield: Thomas.

Kim-Lee MH, Stokes BT, Yates AJ (1992) Reperfusion paradox: a novel mode of glial cell injury. Glia 5:56-64.

Kofuji P, Hadley RW, Kieval R, Lederer WJ, Schulze DH (1992) Expression of the $\mathrm{Na} / \mathrm{Ca}$ exchanger in diverse tissues: a study using the cloned human cardiac $\mathrm{Na} / \mathrm{Ca}$ exchanger. Am J Physiol 263:C1241C1249.

Lazarewicz JW, Kanje M, Sellström Å, Hamberger A (1977) Calcium fluxes in cultured and bulk isolated neuronal and glial cells. J Ncurochem 29:495-502.

Luther PW, Bloch RJ (1989) Formaldehyde-amine fixatives for immunocytochemistry of cultured Xenopus myocytes. J Histochem Cytochem 37:75-82.

Luther PW, Yip RK, Ambesi A, Lindenmayer GE, Bloch RJ, Blaustein MP (1992) Presynaptic localization of sodium/calcium exchangers in neuromuscular preparations. J Neurosci 12:4898-4904.

MacVicar BA, Hochman D, Delay MJ, Weiss S (1991) Modulation of intracellular $\mathrm{Ca}^{++}$in cultured astrocytes by influx through voltageactivated $\mathrm{Ca}^{++}$channels. Glia 4:448-455.

Maniatis T, Fritsch EF, Sambrook J (1982) Molecular cloning, a laboratory manual, pp 446-448. Cold Spring Harbor, NY: Cold Spring Harbor Laboratory. 
Mattson MP, Guthrie PB, Kater SB (1989) A role for $\mathrm{Na}^{+}$-dependent $\mathrm{Ca}^{2+}$ extrusion in protection against neuronal excitotoxicity. FASEB J 3:2519-2526.

McCarthy KD, Salm AK (1991) Pharmacologically-distinct subsets of astroglia can be identified by their calcium response to neuroligands. Neuroscience 41:325-333.

McPherson PS, Kim YK, Valdivia H, Knudson MC, Takekura H, Franzini-Armstrong C, Coronado R, Campbell KP (1991) The brain ryanodine receptor: a caffeine-sensitive calcium release channel. Neuron 7:17-25.

Moore EDW, Fay FS (1993) Isoproterenol stimulates rapid extrusion of sodium from isolated smooth muscle cells. Proc Natl Acad Sci USA 90:8058-8062.

Moore EDW, Etter EF, Philipson KD, Carrington WA, Fogarty KE, Lifshitz LM, Fay, FS (1993) Coupling of the $\mathrm{Na}^{+} / \mathrm{Ca}^{2+}$ exchanger, $\mathrm{Na}^{+} / \mathrm{K}^{+}$pump and sarcoplasmic reticulum in smooth muscle. Nature 365:657-660.

Nicoll DH, Longoni S, Philipson KD (1990) Molecular cloning and functional expression of the cardiac sarcolemmal $\mathrm{Na}^{+}-\mathrm{Ca}^{2+}$ exchanger. Science 250:562-565.

Palade P, Dettbarn C, Alderson B, Volpe P (1987) Pharmacological differentiation between inositol-1,4,5-trisphosphate-induced $\mathrm{Ca}^{2+}$ release and $\mathrm{Ca}^{2+}$ or caffeine-induced $\mathrm{Ca}^{2+}$ release from intracellular membrane systems. Mol Pharmacol 36:673-680.

Parekh AB, Terlau H, Stuhmer W (1993) Depletion of InsP3 stores activates a $\mathrm{Ca}^{2+}$ and $\mathrm{K}^{+}$current by means of a phosphatase and a diffusible messenger. Nature 364:814-818.

Randriamampita C, Tsien RY (1993) Emptying of intracellular $\mathrm{Ca}^{2+}$ stores releases a novel small messenger that stimulates $\mathrm{Ca}^{2+}$ influx. Nature 364:809-814.

Reiländer H, Achilles A, Friedel U, Maul G, Lottspeich F, Cook NJ (1992) Primary structure and functional expression of the $\mathrm{Na} / \mathrm{Ca}, \mathrm{K}-$ exchanger from bovine rod photoreceptors. EMBO J 11:1689-1695.

Salvaterra PM, Matthews DA (1980) Isolation of rat brain subcellular fraction enriched in putative neurotransmitters and synaptic junctions. Neurochem Res 5:181-195.

Schatzmann HJ (1992) The plasma membrane calcium pump of eryth- rocytes and other animal cells. In: Membrane transport of calcium (Carafoli E, ed), pp 41-108. London: Academic.

Seidler NW, Jona I, Vegh M, Martonosi A (1989) Cyclopiazonic acid is a specific inhibitor of the $\mathrm{Ca}^{2+}$-ATPase of sarcoplasmic reticulum. J Biol Chem 264:17816-17823.

Siesjó BK (1991) The role of calcium in cell death. In: Neurodegenerative disorders: mechanisms and prospects for therapy (Price $D$, Aguayo A, Thoenen H, eds), pp 35-59. Chichester: Wiley.

Stys PK, Ransom BR, Waxman SG, Davis PK (1990) Role of extracellular calcium in anoxic injury of mammalian central white matter. Proc Natl Acad Sci USA 87:4212-4216.

Takemura H, Hughes AR, Thastrup O, Putney JW Jr (1989) Activation of calcium entry by the tumor promoter thapsigargin in parotid acinar cells. Evidence that an intracellular calcium pool and not an inositol phosphate regulates calcium fluxes at the plasma membrane. J Biol Chem 264:12266-12271.

Thastrup O, Cullen PJ, Drobak BK, Hanley MK, Dawson AP (1990) Thapsigargin, a tumor promoter, discharges intracellular calcium stores by specific inhibition of the endoplasmic reticulum Ca-ATPase. Proc Natl Acad Sci USA 87:2466-2470.

Towbin H, Gordon J (1984) Immunoblotting and dot immunobinding-current status and outlook. J Immunol Methods 72:313-340.

Tymiak AA, Norman JA, Bolgar M, Didonato GC, Lee H, Parker WL, Lo LC, Berova N, Nakanishi K, Haber E, Haupert GT (1993) Physicochemical characterization of a ouabain isomer isolated from bovine hypothalamus. Proc Natl Acad Sci USA 90:8189-8193.

Walz W (1992) Coupling of metabolism and electrical activity in cortical astrocytes. Can J Physiol Pharmacol 70:S176-S180.

Yamada H, Naruse M, Naruse K, Demura H, Takahashi H, Yoshimura M, Ochi J (1992) Histological study on ouabain immunoreactivities in the mammalian hypothalamus. Neurosci Lett 141:143-146.

Yarowsky PJ, Krueger BK (1989) Development of saxitoxin-sensitive and insensitive sodium channels in cultured neonatal rat astrocytes. J Neurosci 9:1055-1061.

Yip RK, Blaustein MP, Philipson KD (1992) Immunologic identification of $\mathrm{Na} / \mathrm{Ca}$ exchange protein in rat synaptic plasma membrane. Neurosci Lett 136:123-126. 